\title{
Computer Attitudes and Use Among Novice Teachers: The Moderating Effects of School Environment
}

\author{
*WONG KUNG TECK \\ GOH SWEE CHOO \\ HAFIZUL FAHRI HANAFI \\ ROSMA OSMAN \\ Universiti Pendidikan Sultan Idris \\ *(thomas@fskpm.upsi.edu.my)
}

\begin{abstract}
Purpose - This survey research investigated important issues concerning computer use among novice graduate teachers from teacher training colleges in Sabah. The first issue was concerned with the levels of computer attitudes (CA) and computer use. The second was concerned with the effects of CA on computer use (CU). The third was concerned with moderating effects of the school environment (SE) on relationship between CA and computer use.
\end{abstract}

Method - A set of questionnaires was used as the research instrument and stratified systematic sampling was used to determine the research samples. The sample consisted of 192 primary and secondary school teachers. The data were analyzed using descriptive and inferential statistics (factor analysis and regression analysis). Research hypotheses were tested at significance level of $a=0.05$.

Findings - The findings showed that novice teachers have moderate $\mathrm{CA}$ and CU. CA had significant effects on computer use. SE has moderating impacts on the relationships between CA towards CU.

Value - The study provided wider implications for theory development, practices and policymaking that can be associated with the computer use among teachers. As a whole, most of the theoretical rationales used in explaining those relationships have been supported.

Keywords: educational technology, instructional, teacher's attitudes, school environment. 


\section{INTRODUCTION}

Technology in schools has now taken a place in the agenda of international meetings, along with trade and economics. Information and communications technology (ICT) has provided tools to help in the teaching and learning processes. The former Education Minister of Malaysia, Datuk Seri Hishammuddin Tun Hussein has remarked that the growing importance of education is a new international development because every sensible leader recognizes that the economic, social and cultural wealth of a nation in the Information Age lies in its people, and what they know and can do (Ministry of Finance, 2004). In the technological trends of the 21st century, all member countries of the South East Asia Ministers of Education Organization (SEAMEO), including Malaysia, have begun to focus on benefit of information and communications technology to improve the teaching and learning of certain subjects, particularly Science and Mathematics but the benefits from computer learning activities have not yet been fully promoted since many teachers are still not clear with its implementation, either in developing or developed countries (Jintavee, 2005).

In this Information Age, there is a clear recognition that technologies can transform conventional education system and bring more advantages and benefits to Malaysians, especially for the younger generation, and the country as a whole. Thus, Malaysian schools have devoted considerable resource to technology. Malaysian schools and colleges have included computer technology as an integral part of students learning experiences and as a way to equip them with the skills and knowledge necessary to succeed in the $21^{\text {st }}$ century.

In the 2005 national budget, the Malaysian government had allocated a total of RM19.3 billion for the development of the education sector to provide better information and communications the technology facilities to schools and students (Ministry of Finance, 2004). To further strengthen education and training for knowledge based technology, a sum of RM33.4 billion has been allocated for operational and development in the 2007 national budget. Of this, RM6.7 billion has been allocated for primary education, RM6.2 billion for secondary education, RM10.4 billion for higher education and RM10.1 billion for computer training programs. To enhance computer usage in schools, a sum of RM288 million has been allocated under the Smart School Program, which involves the 
procurement of computers and peripherals for the Access Centers in 1,000 schools and in all teacher training colleges (The 2007 Budget Speech, 2006).

Presently, there are limited studies that focus on how teacher educational training programs influence the use of computers either in instructional or non-instructional teaching methods and its levels. Due to a lack of information regarding factors contributing to the use of computers, teachers have not been convinced to use them in their teaching and learning. It is disheartening to note that at the present time, the government, policymakers and teacher educators have not ensured its successful implementation but have been merely promoting technology acceptance. Furthermore, they are not able to guarantee that there will be a high rate of technology acceptance at the individual level after undergoing the teacher educational programs. Morrison and Osborn (2005) have stated that one of the reasons that information and learning technology has not become a lasting factor in education organizations is the educators' lack of self-reported knowledge or proficiency.

Many educators and policymakers for teacher educational programs may not be aware of the factors that can encourage teachers to use the ICT equipment. The potentials of computer applications in education and its full integration in classroom instruction by teachers can only be realized through effective and efficient teacher educational programs. Therefore, this study sets out to examine those factors, specifically the relationship between attitudes, computer use and school environment.

\section{Objectives of the Study}

The main aim of this study is to examine computer attitudes among novice teachers in relation to computer use. In order to achieve this aim, specific objectives have been developed as follows:

1) To examine the levels of computer attitudes and computer use among novice graduates from teacher training colleges.

2) To examine the relationship between computer attitudes (anxiety, liking, confidence and usefulness) and computer use among novice graduate teachers from teacher training colleges.

3) To examine the effects of school environment (administrators and technical support), as moderator variable, in the relationship between computer attitudes and computer use among novice graduate teachers from teacher training colleges. 


\section{REVIEW OF RELATED LITERATURE}

The review of literature have been divided into sections namely computer and education: Malaysian perspective; computer attitudes and computer use; school environment and computer use; and computer use. Based on the literature review, the researchers have proposed the conceptual framework for this study.

\section{Computer and Education: Malaysian Perspective}

The importance of integrating computer in education was highlighted when the Ministry of Education launched the Smart School. The Smart School has become one of the seven flagship applications in Malaysia of the Multimedia Super Corridor (MSC) project in the year 1997 (TakingITGlobal, 2003). According to the Curriculum Development Center (2003), the Smart School project will prepare school leavers for the information age and equip them with information technology competencies. This will help them to develop their potential to face the advancement of technology. This project involves a major transformation of the Malaysian school system. In other words, computer technology is indispensable for the success of the Smart Schools. Multimedia courseware, presentation facilities and e-mail are required in classroom settings, while library and computer laboratories are resources that will facilitate learning and teaching. Some of the expected changes include a more widespread use of computers and related information and communications technology in the classroom, and also teachers' knowledge and skills in computer technology. By the year 2010, all the estimated 10,000 Malaysian schools will be Smart Schools, involving an estimated enrolment of 5.8 million students and 450,000 teachers (Ministry of Education, 1997).

Data extracted manually from information obtained from Sabah Education Department (Information Unit) in 2008 show that within January 2003 to June 2007, 14,760 notebooks and 9,987 units of LCD projectors had been distributed to primary and secondary teachers. From the year 2003 to June 2007, the Ministry of Education has spent about RM15 millions to purchase computer related equipment for Mathematics, Science and English teachers in Sabah which underlies the Pengajaran dan Pembelajaran Sains dan Matematik menggunakan Bahasa Inggeris (PPSMI) program (refer to Table 1). 
Table 1

Total Computer Items Purchased for Mathematics, Science and English Teachers in Sabah (2003 - June 2007)

\begin{tabular}{lcccc}
\hline \multirow{2}{*}{ Year } & \multicolumn{4}{c}{ Item } \\
\cline { 2 - 5 } & $\begin{array}{c}\text { Notebook } \\
\text { (unit) }\end{array}$ & $\begin{array}{c}\text { LCD } \\
\text { (unit) }\end{array}$ & $\begin{array}{c}\text { White Screen } \\
\text { (unit) }\end{array}$ & $\begin{array}{c}\text { Trolley / speaker } \\
\text { (unit) }\end{array}$ \\
\hline 2003 & 8,372 & 7,134 & 1,716 & 3,023 \\
2004 & 593 & 1,242 & 1,237 & 3,022 \\
2005 & 669 & 16 & 0 & 0 \\
2006 & 1,396 & 117 & 3,204 & 3,209 \\
June 2007 & 3,730 & 1,478 & 1,578 & 2,919 \\
Total & 14,760 & 9,987 & 7,735 & 12,173 \\
\hline
\end{tabular}

Source. Data manually retrieved from Sabah Education Department (Information Unit), (2008).

\section{Computer Attitudes and Computer Use}

Technology Acceptance Model (TAM) (Davis, 1989), Theory of Reasoned Action (TRA) (Fishbein \& Ajzen, 1975; Ajzen \& Fishbein, 1980), Theory of Planned Behavior (TPB) (Ajzen, 1985) and MultiAttribute Attitude Model (MAA) (Wilkie \& Pessemier, 1973) have shown the relationship between attitudes and intention or actual behavior. Figure 1 shows the combination of the four models. From the four models, attitudes have been shown to be a good predictor for actual behavior. Thus, the researchers have hypothesized that computer attitudes have a statistical relationship with computer use among novice graduates.

\section{School Environment and Computer Use}

In this study, school environment refers to the support from administrators, such as non-academic staff, principals and senior assistants, and technical support in the teaching and learning process. The researcher has hypothesized that the higher the support from school environment, the stronger the relationship between computer attitudes and computer use among teachers in schools. 


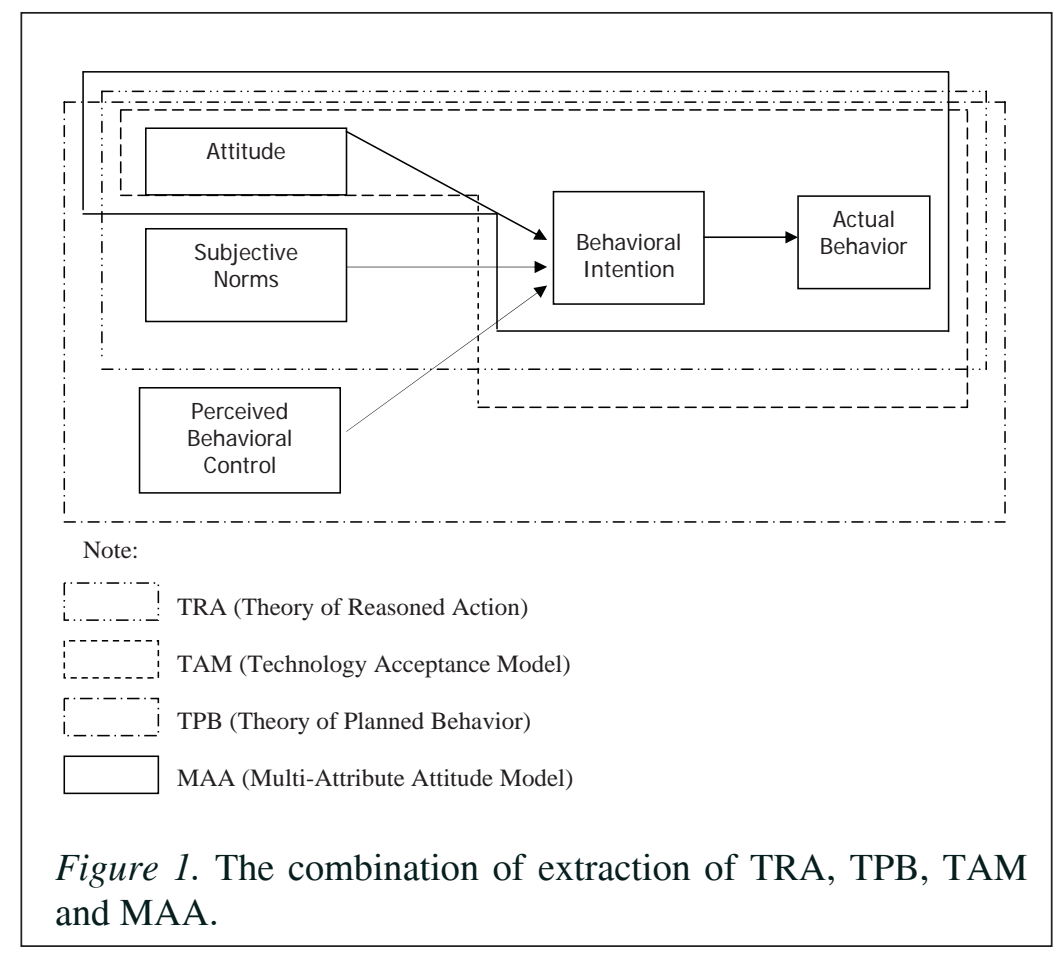

The school environment acts as the moderator variable in the research framework and it is positioned between computer attitudes and computer use. Pajares (2004) indicates that even with positive attitudes, teachers have difficulty embracing the expectation that new technologies can be used effectively. These rapid changes can be overcome by having positive support from school. Motivation and encouragement from administrators and peer are vital in reducing the levels of resistance.

According to Goldstein and Ford's (2002) model, the working environment acts as the moderator between learning outcomes and technology use. Learning outcomes (level of trainee's learning and retention of materials) have significant impact or influence on the transfer outcomes. The extent of transfer of training to the workplace (transfer outcomes) also depends on factors within the workplace (work characteristics).

Many researchers, such as Bandura (1986, 2001), Goldstein and Ford (2002), Mitchell (2003), Wahab (2003), Thelma (2004), Green (2005) and Chan (2007), indicate that effective leadership will be able to facilitate the use of computer and formation of 
positive attitude among teachers. Thus, based on the above literature review, the researchers formed the hypothesis that relationship between computer attitudes and computer use is moderated by school environment.

\section{Computer Use}

Generally, the researchers believe that computer use among teachers is primarily driven by a teacher's work task. Even though, nowadays the teachers' work tasks and responsibilities may vary, there are some common teaching related tasks that can be used to measure the use of computer among teachers. Reynolds' (1992) study note that teaching task can be categorized as pre-active, interactive, and post-active or learning. Reynolds' labels tasks, such as comprehending, preparing and adapting content, plans and materials as pre-active; those tasks performed during instruction as interactive; and tasks that demonstrated reflection on one's own actions and student's responses, interacting with colleagues and continued professional development as post-active. Reynolds (1992) identify that teachers, basically have six tasks. These are identified as, planning for or preparing instruction; managing the classroom; implementing instruction; evaluating student learning and instructional effectiveness; administrative responsibilities; and additional professional responsibilities.

In this study, computer use is divided into planning, instruction, assessment and communication. Reynolds' (1992) first task is analogous to this study's planning component. The second and third tasks were subsumed in this study's instruction component. The assessment component corresponded perfectly to Reynolds' fourth task and finally, in so much as communicating with parents, students and colleagues were part of one's additional professional responsibilities as a teacher and this was included as part of Reynolds' fifth and sixth tasks.

In the conceptual framework (refer Figure 2), the researchers intentionally did not include the "Behavioral intention" construct that was mentioned in TRA, TPB, MAA and TAM as it is not part of the objective of this study. Moreover, since the samples (teachers) have been posted to schools and computer use in school has been introduced to them, the researchers believe that the testing on intention was not necessary. Besides, the researchers had already designed a questionnaire to elicit the information on the actual computer use from the samples. 
In general, a person who believes that performing a given behavior will lead to positive outcomes will hold a favorable attitude toward performing the behavior. Similarly, people who believe that performing a given behavior will lead to negative outcomes will hold an unfavorable attitude toward performing the behavior. Thus, attitude toward the behavior is a function of both the beliefs that the behavior leads to certain outcomes, and by the person's evaluation of these outcomes.

In this study, the computer attitudes variable refers to teachers' attitudes toward computer. Computer attitudes variable included teachers' anxiety, liking, usefulness and confidence levels which have been conceptualized in Gressard and Loyd (1986) study. (i) Computer anxiety: Fear of computer technology accompanied by feelings of nervousness. (ii) Computer Liking: Enjoyment in using computer. (iii) Computer usefulness: The ability to perceive computer as a useful tool. (iv) Computer Confidence: Confidence in learning or using computers. Thus, in this study, it is hypothesized that;

H1 Computer attitudes (CA) (anxiety, confidence, usefulness and liking) have significant correlation with computer use (CU).

H2 The relationship between computer attitudes and computer use (CU) are moderated by school environment (SE).

\section{METHODOLOGY}

Data regarding teachers' computer attitudes, computer use and school environment were collected based on the self-administered method via questionnaire.

The population of this study consisted of novice graduate teachers from five teacher training colleges in Sabah. Some criteria were adopted to determine the actual accessible population. Firstly, the respondents must have gone through the training course on full time basis and be fully trained by those training colleges. Trainee teachers who have gone through combined courses with other higher institutions, such as universities were not eligible for this study. Secondly, the trainees selected were among those who graduated in the year 2004 or 2005 and majored or minored either 
in English, Mathematics or Science. Finally, they must have been appointed as trained teachers and in the mean time were waiting for the confirmation letter from Suruhanjaya Perkhidmatan Awam (SPA). These criteria were considered appropriate and relevant in the context of the study as they ensured that the respondents belonged to the fresh graduate group.

Based on the information dated January 2006 from Information Technology Unit, Sabah Education Department the total numbers of trainee teachers who belonged to this group were 1120. Participation by the teachers was wholly voluntary. The sample size in this study was determined by using Krejcie and Morgan's (1970) guideline for sample size decision.

In this study, the expectation was to procure a $55 \%$ response rate of the distributed questionnaires. The formula for obtaining the number of questionnaires needed to be distributed was [sample size $(291) /$ response rate $(55 \%)=$ distributed questionnaires (529)]. Based on this formula, the researcher has sent out 529 questionnaires which were 47.23 percent of the total population and this was 21.33 percent higher than the suggested sample size by Krejcie and Morgan (1970).

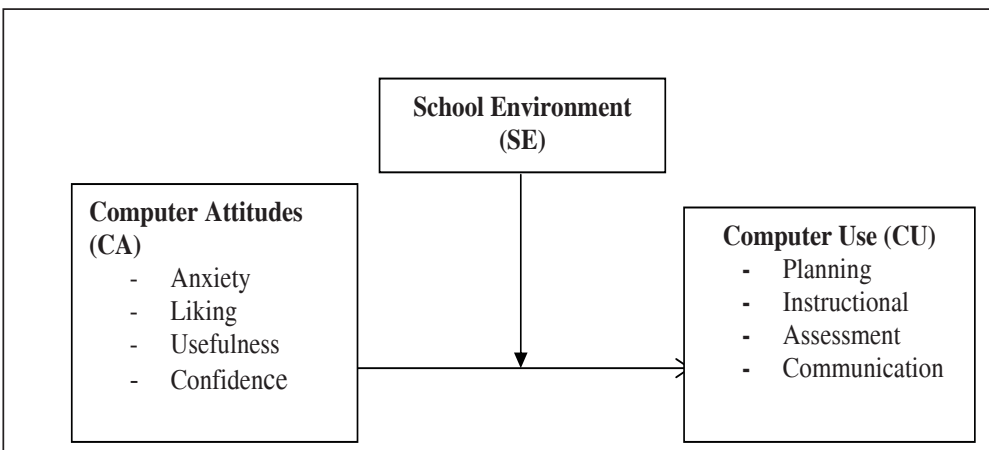

Figure 2. Conceptual framework.

\section{Findings}

The results indicated that there were more female respondents than male respondents. Out of the total 192 respondents, $62.5 \%$ were female and the others were male $(37.5 \%)$. In relation to the age of 
the respondents, the analysis showed that majority (48.4\%) of the teachers were around 26 to 30 years old and were followed by those within the rage of 21 to 25 (31.1\%). Out of the 192 respondents, only 20.3 percent of the sample were above 31 and below 35 of age. Most of the respondents were Malays (71.9\%).

$41.7 \%$ of the respondents majored in Science, while English and Mathematics had $33.3 \%$ and $25 \%$ respectively. Over $42.2 \%$ of the respondents were teaching in primary school and $57.8 \%$ were teaching in secondary schools. From the $42.2 \%$ of primary school teachers, 24\% were teaching Year 1 until 3 and the rest were teaching Year 4 until 6. The data also indicated that most of the respondents were teaching Form 1 to Form 3. The data showed that $32.3 \%$ and $25.5 \%$ were lower primary and upper school teachers respectively. The data showed that the samples were normally distributed from lower primary to upper secondary.

As shown in the Table 2, $43.2 \%$ of the respondents indicated a moderate level of computer attitude. Only $9.9 \%$ or 19 respondents out of 192 respondents had high level of computer use.

Table 2

Distribution of Computer Attitudes and Computer Use Levels

\begin{tabular}{llcccc}
\hline Predictor & $\begin{array}{c}\text { Level } \\
\text { (range of score) }\end{array}$ & Frequency & Percentage & Mean & $\begin{array}{c}\text { Standard } \\
\text { Deviation }\end{array}$ \\
\hline Computer & Low (40-80) & 32 & 17.2 & 106.84 & 24.87 \\
Attitudes & Moderate (81-120) & 83 & 43.2 & & \\
& High (121-160) & 77 & 39.2 & & \\
Computer & Low (12-31) & 71 & 37.0 & 37.68 & 10.37 \\
Use & Moderate (32-52) & 102 & 53.1 & & \\
& High $(53-72)$ & 19 & 9.9 & & \\
\hline
\end{tabular}

Besides the levels of computer attitudes and computer use, the researcher also analyzed the frequency of computer use among teachers based on the ways of computer use (planning, instructional, assessment and communication). As shown in Table 3, 32.1\% of the respondents used the computer for planning, followed by instructional (23.7\%), and communication (22.45\%) purposes. Computer use for assessment purposes was the lowest ranked with only $21.66 \%$. 
Table 3

Distribution of Ways of Computer Use

\begin{tabular}{llc}
\hline Ways of Computer Use & Percentage \\
\hline 1$)$ Planning & $32.1 \%$ \\
2) Instructional & $23.7 \%$ \\
3) Assessment & $21.66 \%$ \\
$4)$ Communication & $22.45 \%$ \\
\hline
\end{tabular}

\section{Hypothesis 1}

Computer attitudes (CA) (anxiety, confidence, usefulness and liking) have significant correlations with computer use (CU).

As shown in Table 4, when the four independent variables were entered into the regression equation, the coefficient of determination (R-square) was found to be 0.369 which indicated that $36.9 \%$ of the variance in the computer use can be explained by the computer attitudes variable (anxiety, confidence, liking and usefulness). The regression output presented in Table 4 indicated that two out of four predictors were found to have an impact and relationships on computer use. Of the computer attitudes variables, only computer confidence $(b=0.365, p<0.01)$ and computer usefulness $(b=0.411$, $\mathrm{p}<0.01$ ) were found to have significant and positive relationships with computer use. Conversely, computer anxiety and computer liking did not have relationship with the computer use. Thus, the Hypothesis was partially accepted.

Table 4

Results of Regression Analysis between Computer Anxiety, Computer Confidence, Computer Liking, Computer Usefulness and Computer Use

\begin{tabular}{lcccc}
\hline \multirow{2}{*}{ Independent Variable } & \multicolumn{2}{c}{$\begin{array}{c}\text { Unstandardized } \\
\text { Coefficients }\end{array}$} & $\begin{array}{c}\text { Standardized } \\
\text { Coefficients }\end{array}$ & \multirow{2}{*}{$\mathrm{t}$} \\
\cline { 2 - 4 } & $\mathrm{B}$ & Std. Error & Beta & \\
\hline Computer Anxiety & -.024 & .082 & -.023 & -.290 \\
Computer Confidence & .365 & .079 & .361 & $4.643^{* *}$ \\
Computer Liking & .077 & .076 & .066 & 1.016 \\
\hline
\end{tabular}

(continued) 


\begin{tabular}{lccc}
\hline \multirow{2}{*}{ Independent Variable } & \multicolumn{2}{c}{$\begin{array}{c}\text { Unstandardized } \\
\text { Coefficients }\end{array}$} & $\begin{array}{c}\text { Standardized } \\
\text { Coefficients }\end{array}$ \\
\cline { 2 - 3 } R - square & B & Std. Error & Beta \\
\hline Unadjusted R - square & & .369 \\
F - value & \multicolumn{2}{c}{.355} \\
Sig - F & \multicolumn{2}{c}{27.310} \\
Durbin - Watson & \multicolumn{2}{c}{.000} \\
\hline
\end{tabular}

$* \mathrm{p}<0.05 ; * * \mathrm{p}<0.01$

\section{Hypothesis 2}

The relationship between computer attitudes (anxiety, confidence, liking, usefulness) and computer use (CU) is moderated by the school environment (SE).

Table 5 depicted the results of the regression analysis for school environment as the moderator in the relation between computer attitudes and computer use. It was discovered that when the interaction terms were added to the regression analysis in the last step, the R- square was 0.428 . The change was about $5.9 \%$ compared to the model that was without inclusion of the moderator variable (school environment). Based on the change of the R-square and F-ratio and its statistical significance, the researcher confirmed that there was a moderating effect by the school environment. In other words, school environment had moderated the relationship between independent predictors and dependent variable as a whole. Thus, this provided full support for the moderating effects hypothesis listed in Hypothesis 3.

In this analysis, while testing the moderating effect, the researcher only interpreted the significant effect in the interaction section (step 3) and did not interpret the beta values in the third step as there is bound to be problems of multicollinearity. Once step 3 shows a significant $\mathrm{R}$ square increase, then it can be concluded that there is moderation effect. Through the Collinearity Statistics, it has been shown that in the interaction section (step 3), the Tolerance was less than .20 and VIF was $\geq 5$, therefore it indicated multicollinearity. 
Table 5

Moderating Impact of School Environment on the Relationship between Computer Attitudes and Computer Use

\begin{tabular}{|c|c|c|c|}
\hline Independent Variable & Beta (Step 1) & Beta(Step 2) & Beta (Step 3) \\
\hline \multicolumn{4}{|l|}{ Main Variables } \\
\hline Computer Anxiety & -0.024 & -0.016 & -0.981 \\
\hline Computer Confidence & $0.365 * *$ & $0.343 * *$ & -1.081 \\
\hline Computer Liking & 0.077 & 0.068 & -1.182 \\
\hline Computer Usefulness & $0.411 * *$ & $0.419 * *$ & $2.645 * *$ \\
\hline \multicolumn{4}{|l|}{ Moderating Variable } \\
\hline School Environment & & 0.052 & -0.792 \\
\hline \multicolumn{4}{|l|}{ Interaction Terms } \\
\hline Computer Anxiety*moderator & & & 0.265 \\
\hline Computer Confidence*moderator & & & $0.461 *$ \\
\hline Computer Liking*moderator & & & $0.409 *$ \\
\hline Computer Usefulness*moderator & & & $0.710 *$ \\
\hline R square & $0.369 * *$ & 0.370 & $0.428 * *$ \\
\hline R square change & - & 0.001 & 0.059 \\
\hline Sig. F change & 0.000 & 0.603 & 0.000 \\
\hline Durbin Watson & & 1.665 & \\
\hline
\end{tabular}

$* \mathrm{p}<0.05 ; * * \mathrm{p}<0.01$

To show the moderating effect of school environment on the computer attitudes and computer use relationship more clearly, graphs have been drawn. The variables were re-categorized into two levels, high and low before the graph was drawn as both variables were continuous. The 2 levels were based on the median where any value lower than the median was categorized as low level and values above the median were assigned as high level. The results of the significant interactions have been presented in Figure 3.

As can be seen in Figure 3, the relationship between computer attitude and computer use was moderated by school environment and the change in the level of computer use was positive and constant. On examining the specific interaction, the graph has shown the intersection and it explained that school environment variable did not have high moderating impacts for those who are having high level of computer attitude. In this study, the Hypothesis was accepted. 


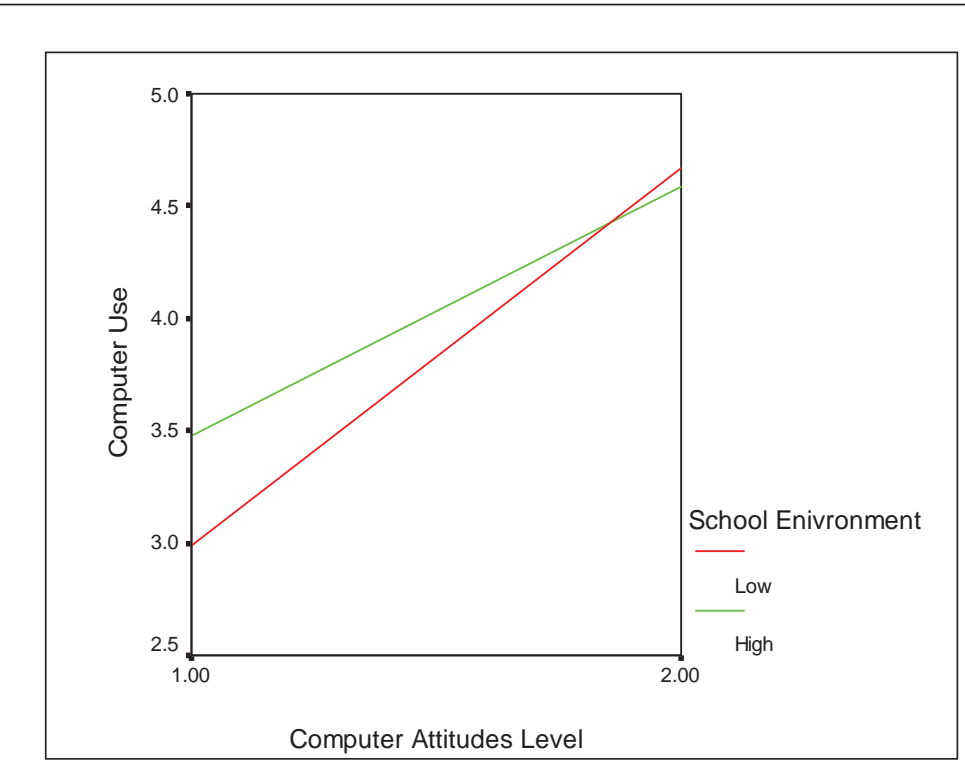

Figure 3. The moderating effect of school environment on the computer attitudes and computer use.

In general, efforts should be made to encourage more positive computer attitudes among teachers, since many findings from the previous researches and the results have indicated that computer attitudes have significant impact on teachers' acceptance of technology. Schools should provide the training, funding and support required for this process. By strengthening staff training in technologies, schools can help encourage more positive attitudes toward computers, especially to reduce teachers' anxiety towards computer in general. Thus, the school boards of management should ensure that in-service technology training program be a part of their yearly activities.

Meeting the needs related to technology integration and helping to instill more favorable computer attitudes will directly assist in the integration of computer into the teaching and learning activities.

\section{School Environment}

This study reports that school environment has moderating impacts on the relationship between computer attitudes and computer 
use. The significance of school environment in enhancing the relationships between computer attitudes and computer use could be due to the fact that teachers need administrative and technical support to encourage them to use the computer. Teachers need strong and enthusiastic leadership from principals in order to achieve higher confidence and belief in the use of computers. Technical support is vital when teachers are having difficulties in operating the computer based technologies equipment. Having knowledgeable people and willingness to answer questions are critical in overcoming the obstacles to use computer. In Malaysian schools, especially in the rural areas, lack of availability of computers and software, and incompatibility between the software and hardware are very common situations. Most teachers may know how to 'operate' a computer but do not know or understand its benefits. Training for principals is vital in ensuring that they are conscious of the importance of computer in teaching and learning. Through training, they would be able to know how to encourage (giving coaching, feedbacks and leading) teachers to use computers.

Many teachers have voiced out that the number of computers in their classrooms was insufficient. Lack of equipment could be construed as a barrier for teachers in using technology, as well as to further integrate technology in creative and innovative ways.

School districts should look for different funding resources to make computer technologies available for each teacher and in each classroom. Principal or headmasters should give motivation and support to their staff and encourage them to use computer although at the initial level it could be very difficult.

In short, computer attitudes were found to be significant predictors of computer use among teachers. In this study, the important implication for theoretical development is related to computer attitudes and school environment towards computer use. The findings have also shown that school environment factor positively affects the use of computer in school. This study concludes that computer attitudes have statiscally significant relationship to the computer use among teachers. In this study, the researchers also discovered that school environment has moderating impacts on the relationships between computer attitudes and computer use.

\section{CONCLUSIONS}

This study has been conducted in only one state and on a relatively small number of novice teachers. No formal generalization is 
possible, but it is interesting to speculate whether similar results might be found if the samples were extended to a wider group, from other Malaysian states, and other teaching disciplines. However, there is no strong reason for novice teachers from the participating teaching institutions to be seen as markedly different in their attitudes from other novice teachers from other teacher education institutions. This does suggest that there is still good reason for others to examine data from their own institutions to see whether similar (or dissimilar) factors contribute to novice teachers' attitudes and confidences.

The study has essentially raised further questions, such as: How can schools harness the knowledge gained from this study to improve attitudes?; How can schools and teaching curricula address these technological issues and effect change in attitudes among novice teachers?; or Can ongoing professional development support the integration of ICT, that is so critical to schools? These are some questions that need to be explored further. Studies on aspects of computer attitudes and school environments are not only time intensive but also quite expensive to conduct on a large scale. However, if the results would assist the government in making policy and funding decisions that would ultimately improve student learning as well as increase the confidence of novice teachers in using ICT, then the efforts would be worthwhile.

\section{REFERENCES}

Ajzen, I., \& Fishbein, M. (1977). Attitude behavior relations: A theoretical analysis and review of empirical research. Psychological Bulletin, 84, 888-918.

Ajzen, I., \& Fishbein, M. (1980). Understanding Attitudes and Predicting Social Behavior. Englewood Cliffs, New Jersey: Prentice-Hall.

Ajzen, I. (1991). The Theory of Planned behavior, Organizational Behavior and Human decision Processes, 50, 179-211.

Bandura, A. (1977). Self-efficacy: Toward a unifying theory of behavioural change. Psychological Review, 84, 191-215.

Bandura, A. (1982). Self-efficacy mechanism in human accuracy. American Psychologist, 37(2), 122-147.

Bandura, A. (1986). The explanatory and predictive scope of selfefficacy theory. Journal of Social Clinical Psychology, 4, 358 -373 . 
Bandura, A. (1986). Social foundations of thought and action: A social cognitive theory. Englewood Cliffs, New Jersey: Prentice-Hall.

Bandura, A. (1988). Organizational applications of social cognitive theory. Australian Journal of Management, 13, 275-302.

Bandura, A. (1993). Perceived self-efficacy in cognitive development and functioning. Educational Psychologist, 28(2), 117- 148.

Bandura, A. (1997). Self-efficacy: The exercise of control. New York: Freeman.

Bandura, A. (2001). The changing face of psychology at the dawning of a globalization era. Canadian Psychology, 42, 12-24.

Brooks, G.P. (2004). Sample size determination. Retrieved on 29 April 2007. from http://oak.cats.ohiou.edu/ brookssb/edre/ edre720_samplesize.pdf.

Cassidy, S., \& Eachus, P. (2002). Developing the computer user self-efficacy (CUSE) scale: Investigating the relationship between computer self-efficacy, gender and experience with computers. Journal of Educational Computer Research, 26(2), 133-154.

Chan, L. H. (2007), Perceived importance and manageability of teachers toward the factors of integrating computer technology into classrooms. Innovation in Education and Teaching International, 44(1), 44-55

Cuban, L., Kirkparick, H., \& Peck, C. (2001). High access and low use of technology in high school classrooms: Explaining an apparent paradox. American Educational Research Journal, 38(4), 813-834.

Cuban, L. (1986). Teachers and machines. New York: Teachers College Press.

Cuban, L. (1996). Techno-reformers and classroom teachers. Education Week, 16(6), 31-46.

Cuban, L. (1993). How teachers taught: Constancy and change in American classrooms: 1890-1990 (2nd ed.). New York: Teachers College Press.

Cuban, L. (2001). Oversold \& underused: Computers in the classroom. Cambridge, MA: Harvard University Press.

Curriculum Development Center. (2003). Malaysia's Smart School Project. Retrieved 14 January, 2004, from http://202.190.218.3/smartschool/.

Davis, F.D. (1989). Perceived usefulness, perceived ease of use and user acceptance of information technology. Management Information Systems Quarterly, 13 (3), 983-1003. 
Enochs, L.G. (1985). General attitudes of middles school students towards computers. Journal of Computers in Math and Science Teaching, 5, 56-57.

Enochs, L.G., \& Riggs, I.M. (1990). Further development of an elementary science teaching efficacy belief instrument: A pre service elementary scale. School Science and Mathematics, 90, 694-706.

Enochs, L.G., Riggs, I. M., \& Ellis, J. D. (1993). The development of partial validation of microcomputer utilization in teaching efficacy beliefs instrument in a science setting. School Science and Mathematics, 93, 257-263.

Enochs, L., Smith, P. L., \& Huinker, D. (2000). Establishing factorial validity of the mathematics teaching efficacy beliefs instrument. School Science and Mathematics, 10, 94-202.

Eyadat, W. (2006). Assessing students' and professors' attitudes toward the use of computer-based technology in the classroom: A case study at the University of Jordan. (Unpublished doctoral dissertation). University of Southern California.

Fishbein, M., \& Ajzen, I. (1975). Belief, attitude, intention and behavior: An introduction to theory and research. MA: Addison-Wesley.

Fraenkel, J. R., \& Wallen, N. E. (2003). How to design and evaluate research in education. New York: McGraw-Hill Companies, Inc.

Gibson, C. (2001). Me and us: differential relationships among goal setting training, efficacy and effectiveness at the individual and team level. Journal of Organisational Behaviour, 22, 789-808.

Gibson, S., \& Dembo, M.H. (1984). Teacher efficacy: A construct validation. Journal of Educational Psychology, 76(4), 503-511.

Goldstein, I.L., \& Ford, K.J. (2002). Training in Organizations; Needs assessment, development and evaluation. Belmont, CA: Wadsworth Thomson Learning.

Green, J. D. (2005). The impact of teacher self efficacy and attitudes toward classrooms computers on the use of classroom technology (Unpublished doctoral dissertation). Graduate School of Wayne State University, Detroit, Michigan.

Gressard, C.P., \& Loyd, B. H. (1986). Validation studies of a new computer attitude scale. Association for Education Data Systems Journal, 19, 295-301. 
Hair, J. E., Anderson, R. E., Tatham, R.L., \& Black, W. C. (1998). Multivariate data analysis (4th ed.). Englewood Cliffs, NJ: Prentice-Hall.

International Society for Technology in Education (2004). Education \& industry leaders urge congress to restore education technology funding. Retrieved on 22 March 2004, from http:// www.iste.org/news/2004/09/ 09edtechfunds/.

Jarrett, O.S. (1999). Science interest and confidence among preservice elementary teachers. Journal of Elementary Science Education, 11(1), 49-59.

Jintavee M. (2005). Technology preparation in teacher education programs at public universities in Bangkok (Unpublished doctoral dissertation). Faculty of Graduate School, Texas A \& M University- Commerce.

Krejcie, R.V. \& Morgan, D.W. (1970). Determining sample size for research activities. Education and Psychological Measurement, 30(3) 607-610.

Marcinkiewicz, H. R. (1994). Computers and teachers: Factors influencing computer use in the classroom. Journal of Research on Computing in Education, 26(2) 220-237.

Ministry of Education. (1997). Smart school flagship application: The Malaysian smart school-A conceptual blueprint. Putrajaya: Government of Malaysia.

Ministry of Finance. (2004). The budget speech 2005: Building on past achievements towards greater success. Putrajaya: The Government of Malaysia.

Mitchell, A. C. (2003). Computer use among high school educators: Relating teachers' ability, beliefs, and classroom use (Unpublished doctoral dissertation). School of Education, Fordham University.

Morrison, J.L. \& Osborn, H. (2005). Implementing organic education: An interview with Hugh Osborne. Innovate. Retrieved 12 January 2006. http://www. innovateonline.info/ index.php?view+article\&id=236.

Pajares, F. (2004). Albert Bandura: Biographical sketch. Retrieved 12 September 2005 from http://des.emory.edu/mfp/bandurabio .html.

Reynolds, A. (1992). What is competent beginning teaching? A review of the literature. Review of Educational Research, 62(1), 1-35. 
Riggs, I.M., \& Enochs, L.G. (1990). Toward the development of an elementary teacher's science teaching efficacy belief instrument. Science Education, 76, 625-637.

Ropp, M. M. (1999). Exploring individual characteristics associated with learning to use computers in pre-service teacher preparation. Journal of Research on Computing in Education, 31(4), 402-4425.

TakingITGlobal. (2003). TakingITGlobal projects/ Smart schools. Retrieved 17 January 2004, from http://projects.takingitglobal. org/projectview.html? Project ID=580.

The 2007 Budget Speech. (2006). Retrieved on 8 March 2007, from http://www.bnm.gov.my/files/budget2007.en.pdf.

Thelma, M.H. (2004). Stages of concern and factors that influence middle school teacher's computer technology use (Unpublished doctoral dissertation). Graduate School, Baylor University.

Torkzadeh, R., Pflughoeft, K., \& Hall, L. (1999). Computer selfefficacy, training effectiveness and user attitudes: An empirical study. Behaviour \& Information Technology, 18(4), 299-309.

Tracey, J.B., Hinkin, T. R., Tannenbaum, S.I., \& Mathieu, J. E. (2001). The influence of individual characteristics and the work environment on varying levels of training outcomes. Human Resource Development Quarterly, 12(1), 5-22.

Wahab, S.A. (2003). Factors correlating with teachers' use of computer in the classroom (Unpublished doctoral dissertation) School of Education, DePaul University.

Wilkie, W.L., \& Pessemier, E. A. (1973). Issues in marketing's use of multi-attribute models. Journal of Marketing Research, 11, $428-41$. 